\title{
DEOLOGIEKRITIEK NA(AR) MARX. EEN UITSNEDE UIT HET RECENTE WERK VAN DE FRANKFURTER SCHULE
}

\author{
Barbara Haverhals
}

\section{Inleiding}

De publicatie van John Rawls' A Theory of Justice (1971) riep heel wat reacties op tegen de analytische werkwijze waarmee Rawls zijn theorie had uitgebouwd. De principes die hij hanteert om de rechtvaardigheid van een samenleving te evalueren, zijn het resultaat van louter filosofisch denkwerk. Ze vloeien voort uit een gedachteconstructie waarin denkbeeldige personages met het oog op een ideaal-rechtvaardige maatschappij voor deze principes opteren.

Een belangrijk bezwaar bij deze aanpak kwam van Michael Walzer: een theorie die zich baseert op uitgedachte principes zweeft abstract boven de realiteit waar ze een corrigerende greep op wil krijgen. Kortom, een dergelijke theorie is onbruikbaar voor de praktijk. Om haar praktische ambities waar te maken moet de theorie haar principes laten aansluiten bij de reeds bestaande normen van de (niet-ideale) samenleving waarop ze kritisch wil inwerken.

Op dit punt reageert de kritische traditie van Frankfurt bij monde van Axel Honneth. Honneth gaat met Walzer akkoord dat een kritische theorie bij de maatschappelijke praktijk moet aansluiten. Maar hij verwerpt diens voorstel om de kritische norm dan maar gewoon aan de gevestigde common sense te ontlenen. Dat laatste gaat namelijk in tegen de ideologiekritische bekommernis van Marx, die de Frankfurter Schule tot op vandaag in ere wil houden.

Hieronder volgt eerst een korte terugblik op het probleem van de ideologie en haar kritiek, dat Marx aan de orde stelde. Hedendaagse theorieën die zichzelf 'kritisch' noemen, dreigen die problematiek uit het oog te verliezen wanneer ze zich - vanuit een politiek-filosofisch standpunt - vooral toespitsen op de (liberale) kwestie van rechtvaardigheid. Hierdoor worden ze ongevoelig voor dieperliggende maatschappelijke evoluties die Marx met noties als 'vervreemding' of 'rëificatie' ter sprake bracht, en die Honneth onder de noemer van 'sociale pathologieën' opnieuw onder de aandacht wil brengen.

De tweede sectie overloopt in grote lijnen hoe Jürgen Habermas met zijn 'communicatieve wending' het statuut van de kritische theorie in veiligheid heeft willen brengen, nadat zijn voorgangers Horkheimer en Adorno de rationaliteit als 
zodanig onder verdenking hadden gesteld.

Honneth erkent het belang van Habermas' ingreep, maar hij heeft er ook bezwaren bij die we in de derde sectie zullen toelichten. Om die bezwaren op te vangen wil Honneth aan de hegeliaanse notie van 'erkenning' - die vooral bij de jonge Marx nog sterk aanwezig was - hernieuwd gewicht toekennen.

De vierde sectie legt uit hoe Honneth het kritisch potentieel van deze notie onderscheidt van de ideologische functie die de strijd om erkenning eveneens kan vervullen.

Tot slot volgt een algemene richtlijn waaraan een ideologiekritische benadering van het huidige kapitalisme zich volgens Honneth kan oriënteren.

\section{De ideologische verblinding als effect van een sociale pathologie}

Om te vermijden dat een kritische theorie abstract gaat zweven boven de realiteit waarin ze invloed wil hebben, moet ze haar band met die realiteit methodisch kunnen waarborgen, aldus Honneth. Hiertoe kan ze, bijvoorbeeld, haar standpunt laten aansluiten bij de normatieve ideeën en voorstellingen van de maatschappij die ze kritisch evalueert. Vanuit de ideologiekritische traditie die de Frankfurter Schule na Marx wil verder zetten, wijst Honneth deze optie evenwel af als onvoldoende kritisch. Ze stelt te weinig vragen bij de heersende ideeën die in een bepaalde maatschappelijke context een algemene aanhang vinden en daaraan hun geldingskracht ontlenen.

De zin en inzet van deze scepsis komt goed tot uiting in Marx' kritiek op de 'politieke economie van de burgerij'. Een discours waarin het recht op eigendom wordt afgeleid vanuit de arbeid, naar het motto: wat ik door eigen arbeid heb verkregen, komt mij ook toe als eigendom. Marx laat zien hoe deze legitimatie van eigendomstitels (die in de filosofie door Locke bekrachtigd wordt) net opduikt in een historische periode waarin veeleer het tegendeel waar is. Kortom, in een sociaal-economische context waarin de eigenaar van kapitaal geen arbeid levert en de arbeider geen eigendom bezit, zodat hij zijn arbeid voor een hongerloon op de markt moet verkopen. De heersende idee dat arbeid en eigendom intern samenhangen duikt dus op in een context waarin eigendom en arbeid de facto uit elkaar zijn gehaald.'

Marx beweert evenwel niet dat de bezittende klasse deze heersende idee bewust zou promoten om de arbeidersklasse willens en wetens in de verdrukking te houden. Voor hem zijn arbeiders én kapitalisten in gelijke mate verblind door de ideologie die de ware toedracht van hun onderlinge relaties verhult. Hieruit mag blijken dat Marx' notie van ideologie nog iets meer inhoudt dan wat men daar veelal onder verstaat: een ideeëngoed waarmee men het eens of oneens kan zijn en waarover dan in discussies van mening kan gewisseld worden. Bij Marx is de ideologie een latente, onbewust misleidende kracht die ons doen en denken 
aanstuurt, zonder dat we daar erg in hebben.

In de vroege Economisch-filosofische Manuscripten van 1844 is de ideologische verblinding het symptoom van een vervreemde maatschappij waarin de kapitalistische productiewijze geleid heeft tot een belemmering en onderdrukking van de 'levende arbeid', dit is een maatschappelijkearbeidspraktijk waarin de sociale aard van elke mens zich ten volle kan ontplooien.

In het latere werk verdwijnt de initiële notie van vervreemding naar de achtergrond. De ideologische verblinding is nu te wijten aan een proces van reificatie (Verdinglichung) dat door de kapitalistische winstcreatie in de hand wordt gewerkt. Reïficatie betekent dat de werkelijkheid van tussenmenselijke relaties gaat verschijnen als een samenhang van dingen die als koopwaar met elkaar in omloop treden. Hierdoor geraakt de mens omzeggens in de ban van een permanente categorieënfout. De waarde van de dingen lijkt een mysterieuze (sinnlich-übersinnliche) kwaliteit van de dingen zelf. Maar in waarheid is die verschijningsvorm ten gronde bepaald door het kapitalistische productiesysteem. $^{2}$

Ongeacht hun verschillen wijst Marx met de noties van 'vervreemding' en 'reïficatie' op een pervertering van tussenmenselijke relaties waardoor sommige mensen over hun medemens gaan heersen. De heerschappij van kapitalisten over arbeiders - van mensen over mensen - druist echter in tegen de sociale natuur van het menszijn zelf. Met andere woorden, de kapitalistische maatschappijvorm verblindt het bewustzijn van beide klassen omtrent hun ware aard als mens. Om die reden is het kapitalisme slechts een fase van verdeeldheid die de mensheid verhindert om haar lot bewust en collectief in eigen handen te nemen. Pas in de socialistische fase, die Marx als een historisch doel voor ogen houdt, wordt het zakelijke domein van de dingen institutioneel gescheiden van de tussenmenselijke sfeer waarin die dingen geproduceerd worden. Daar zal de heerschappij van mensen over mensen uiteindelijk plaats maken voor een collectieve 'administratie' van de dingen, dit is van de wijze waarop ze geproduceerd en verdeeld worden.

Uit het voorgaande kan blijken dat Marx' opvatting van de ideologische verblinding verwant blijft met de hegeliaanse dualiteit tussen enerzijds, een illusoire fenomenale werkelijkheid die het bewustzijn ten onrechte voor waar neemt en anderzijds, een ware werkelijkheid die achter de illusie schuilgaat en door de theorie onthuld kan worden. ${ }^{3}$ Op grond van een geprivilegieerd weten omtrent de toekomst, acht de theorie zichzelf in staat om de schijn te doorprikken en het foutieve bewustzijn op te helderen.

Die veronderstellingen en prognoses van het historisch materialisme - of het zogenaamde wetenschappelijke marxisme - zijn naderhand onhoudbaar gebleken. Ook de speculatieve, finalistische visie op de geschiedenis, die na 
Marx ook Lukács nog hanteerde, is vandaag nog moeilijk vol te houden. Niettemin blijft de Frankfurter Schule de zin en bestaansreden van Marx' emanciperend project tot op vandaag verdedigen. Alleen vereist dat project vandaag een vernieuwd theoretisch kader dat in de geest van Marx kritisch gericht kan blijven op de ideologische vertekening of pervertering van maatschappelijke relaties. Dat deze onderneming van zichzelf heel wat meer vergt dan wat de meeste kritische stromingen vandaag onder hun taak verstaan, heeft precies te maken met de diverse krachtlijnen die in het werk van Marx samenkomen en die de kritische traditie van Frankfurt nog steeds - op de ene of andere manier - gecombineerd wil houden.

Om de bijzondere aard van een ideologiekritische theorie te verduidelijken haal ik uit diverse publicaties van Honneth twee kenmerken naar voor waarin hij zijn traditie contrasteert met hedendaagse benaderingen die zich wel 'kritisch' noemen, maar zich amper bezighouden met de problematiek van de ideologie en haar kritiek. Hierbij buigt Honneth zich vooral over de theoretische moeilijkheden waarmee een ideologiekritische aanpak vandaag te kampen heeft, en lijkt hij minder geneigd om daar meteen ook oplossingen voor uit te werken. Deze behoedzame werkwijze is hoe dan ook verhelderend en illustreert de scepsis waarmee Honneth de oplossing van Habermas ter zake van in het begin onthaald heeft.

Het eerste kenmerk en meteen ook de sterkte van een links-hegeliaanse theorie ligt in haar ambitie om een sociologische verklaring te zoeken voor een cruciale vraag die de meeste kritische stromingen zich vandaag nog amper stellen. $\mathrm{Zij}$ nemen er genoegen mee om onrecht aan te klagen op basis van goed gefundeerde of algemeen aanvaarde normen. Maar waarom - zo luidt nu die cruciale vraag komen de slachtoffers voor wie de theorie het opneemt, dan niet zelf in opstand tegen het onrecht dat hen volgens die theorie wordt aangedaan?

In Eine soziale Pathologie der Vernunft legt Honneth uit hoe het komt dat een ideologiekritische theorie deze vraag niet naast zich neer kan leggen. De wantoestanden die een theorie aanklaagt, zouden meteen ook aan de basis kunnen liggen van het feit dat de slachtoffers in de praktijk geen weerstand bieden. Subtiele vormen van geweld kunnen mensen onderhuids immuniseren tegen het onrecht dat hen objectief gezien wordt aangedaan. Ze ondergaan het zonder daar erg in te hebben, of sterker nog, ze stemmen er zelf mee in. De meest doeltreffende vorm van onderdrukking is bereikt wanneer mensen zich zo gaan schikken in hun situatie dat ze uiteindelijk zichzelf, van binnenuit, in de verdrukking houden. Al deze mogelijkheden mogen niet ontsnappen aan het oog van een theorie die zich terecht kritisch noemt. Zo'n theorie moet zich - op een 
of andere manier - kunnen afschermen tegen de ideologische verblinding waarvoor Marx met zijn noties van 'vervreemding' en 'reïficatie' argwaan heeft gewekt.

Hierboven zagen we dat Marx met deze noties verwijst naar maatschappelijke evoluties die de tussenmenselijke relaties vertekenen of perverteren zonder dat we dit beseffen. Om theoretisch alert te blijven voor dergelijke evoluties vat Honneth ze samen onder de gemeenschappelijke noemer van 'sociale pathologieën'. Naast 'vervreemding' en 'verzakelijking' vallen hieronder ook andere varianten die na Marx in de Frankfurter Schule ter sprake kwamen: de 'verblindings-samenhang' bij Horkheimer en Adorno, de 'ééndimensionaliteit' bij Marcuse, het 'positivisme' bij Habermas. Voor Honneth verwijzen al deze noties naar een 'sociale pathologie', een sluipende verzieking van het sociale leven.

Langs deze weg belanden we nu bij het tweede kenmerk waarmee Honneth zijn traditie typeert. Heel wat kritische stromingen vertrekken vandaag vanuit een politiek-filosofische invalshoek die is afgestemd op de problematiek van (on)rechtvaardigheid. Ze zijn voornamelijk begaan met het formeel politiekjuridische kader waarbinnen elke burger de vrijheid moet krijgen om zelfgekozen doelen te realiseren, zolang die maar verenigbaar blijven met de gelijke vrijheid van anderen.

Maar hoe staat het met de invulling van die 'zelfgekozen doelen'? En in hoeverre kiezen we die doelen eigenlijk zelf? Zou het niet kunnen dat we daarin onbewust verleid of misleid worden door ideologische mechanismen die vooral de kapitalistische winstcreatie dienen? Dergelijke vragen vallen doorgaans buiten het domein dat theorieën van rechtvaardigheid voor zichzelf afbakenen. De vraag naar de invulling wordt doorgaans als een ethische kwestie afgeschoven naar de private sfeer, waar elke burger voor zichzelf kan uitmaken wat het betekent om voorbij het loutere overleven - ook een 'goed leven' te leiden. Maar zijn we in die private ethische keuzes dan niet bepaald en beperkt door het aanbod van opties waarin de samenleving als geheel voorziet?

Uiteraard ligt in het streefdoel van een rechtvaardige samenleving al heel wat ethiek besloten. Maar toch is een rechtvaardige samenleving niet automatisch ook een goede samenleving. Althans niet in de geest van Marx voor wie die beide kwesties innig samenhangen. Onrecht houdt bij Marx nog iets meer in dan een inbreuk op formele principes van rechtvaardigheid of een schending van rechten. Onrecht is ook het symptoom waarin een verzieking van het sociale leven tot uiting komt, het gevolg van een evolutie die geen recht doet aan de sociale aard van het menszijn en zo de voorwaarden aantast waarop mensen aangewezen zijn om zich als mens te ontplooien.

Volgens Honneth was Marx meer geïnteresseerd in dergelijke pathologische evoluties dan in de problematiek van rechtvaardigheid zoals die 
vandaag in andere kritische stromingen behandeld wordt. ${ }^{5}$ Een kritische theorie die in de geest van Marx wil verder werken moet dus ook afgestemd blijven op de diagnose van sociale pathologieën.

Theoretische achtergrond. De reactie van Habermas op Horkheimer en Adorno

Tot dusver zagen we hoe Honneth zijn ideologiekritische traditie op twee punten onderscheidt van andere kritische stromingen. Hieronder gaan we na wat Honneth motiveerde om terug te keren naar het werk van Marx en de notie van sociale pathologieën in zijn eigen werk centraal te stellen.

We beginnen met een korte terugblik op de maatschappijkritiek van Horkheimer en Adorno. Hun diagnose was zo drastisch dat Habermas zich genoopt zag om in de kritische traditie van Frankfurt een 'communicatieve wending' door te voeren. ${ }^{6}$ De bezwaren die Honneth bij deze ingreep aantekent, gaan terug op twee methodische vereisten waaraan een links-hegeliaanse theorie volgens hem moet beantwoorden. Op basis van die vereisten kan Honneths kritiek op Habermas' theorie in de volgende sectie verduidelijkt worden.

$\mathrm{Na}$ afloop van de Tweede Wereldoorlog publiceren Horkheimer en Adorno met hun Dialektik der Aufklärung (1947) een historisch-filosofisch narratief waarin ze de doorbraak van totalitaire machtssystemen terugvoeren naar enkele verderfelijke kiemen die de menselijke soort van bij haar ontstaan in zich leek te dragen. De totalitaire obsessie met controle en beheersing lag volgens hen van meet af aan besloten in de arbeid waarmee de mens om te overleven de natuur aan zich moet onderwerpen.

Deze zienswijze was alleszins vernieuwend omdat Marx aan de menselijke arbeid vooral een positieve invulling gaf. Maar ze was ook vernauwend, omdat het arbeidsbegrip van Marx niet alleen slaat op de verhouding van de mens tot de natuur, maar ook de tussenmenselijke relaties omvat waarin de arbeid plaats vindt. Horkheimer en Adorno reduceren het rijke arbeidsbegrip van Marx - dat dus zoals bij Hegel ook een expressieve en intersubjectieve dimensie omvat - tot het manipulerende, controlerende aspect van de natuurbeheersing. Uit dat rijke begrip weerhouden ze enkel het subject-object schema waarin de menselijke relatie tot de natuur wordt gevat. Het resultaat is een soort vervalsgeschiedenis waarin de arbeidspraxis een instrumentele rationaliteit heeft bevorderd die mettertijd is uitgegroeid tot een allesoverheersend, disciplinerend systeem waaraan de hedendaagse mens evenzo weerloos uitgeleverd is als eertijds aan de wilde natuurkrachten. ${ }^{\text {? }}$

Het belangrijkste bezwaar van Jürgen Habermas is gericht tegen de eenzijdige, veel te enge notie van rationaliteit waarrond Horkheimer en Adorno 
hun maatschappijkritiek opbouwen. Doordat ze de instrumentele rationaliteit gelijkschakelen met de rationaliteit als zodanig, brengen ze in dezelfde beweging ook het rationele statuut van hun eigen theorie in het gedrang. Hun kritiek op de ontwikkelingen van de Rationaliteit is zo totaal dat ze geen ruimte meer laat voor een rationeel standpunt van waaruit het ontstaan van recht en democratie als redelijke verworvenheden kunnen afsteken tegen het verval dat ze aanklagen. Nochtans doen ze zelf een beroep op zo'n alternatief standpunt: de plausibiliteit en zeggingskracht van hun kritiek is impliciet ontleend aan de idee of het kritische ideaal van een andere rationaliteit.

Om het redelijk statuut van de kritische theorie veilig te stellen maakt Habermas een duidelijk onderscheid tussen twee vormen van rationaliteit die elk hun eigen logica en bestaansreden hebben, omdat ze aansluiten bij verschillende basale menselijke interessen. Tegenover de instrumentele rationaliteit die zich in de sfeer van de arbeid heeft ontwikkeld, plaatst Habermas de communicatieve redelijkheid die zich ontplooit in het medium van de tussenmenselijke, talige interactie. ${ }^{8}$ De maatschappijkritiek van zijn voorgangers kan nu begrepen worden als een aanklacht tegen een eenzijdige rationalisering waarbij de efficiëntieimperatieven van de instrumentele rationaliteit in alle domeinen van het maatschappelijk leven binnendringen zodat de dialoog over de doelen en de organisatie van deze domeinen in verdrukking komt en stilvalt. De communicatieve redelijkheid van de leefwereld wordt aldus 'gekoloniseerd' door de rationaliteit van het systeem.

Met deze diagnose wijst Habermas op een verzieking van de leefwereld of - in de termen van Honneth - op een sociale pathologie die de problematiek van rechtvaardigheid weliswaar omvat, maar toch ook dieper aanzet omdat elke reactie tegen onrecht blijkbaar geen stem of medium meer vindt om van zich te laten horen. De vervreemde maatschappij van de vroege Marx neemt in Habermas' tijdsdiagnose de gedaante aan van een 'verstomde maatschappij' die uitgeleverd is aan de macht van een systeem waartegen de menselijke leefwereld zich niet meer kan verweren. In deze diagnose ziet Habermas meteen een nieuwe opdracht weggelegd voor de kritische theorie: ze moet de communicatieve redelijkheid die in de leefwereld nog hier en daar te vinden is, aanzwengelen om een tegenmacht te genereren die de leefwereld kan bevrijden van de druk van het systeem.

Honneth heeft evenwel ook een aantal bezwaren bij deze 'communicatieve wending' die Habermas in reactie op Horkheimer en Adorno in de kritische traditie van Frankfurt doorvoerde. Zijn bezwaren hebben onder meer betrekking op twee methodische kwesties die hij uitlegt in een korte publicatie met de titel 


\section{Moralbewußtsein und sozialer Klassenherrschaft. ${ }^{9}$}

Aan het begin van dit artikel betwijfelt Honneth de bijna algemeen aanvaarde these dat de marxistische klassenstrijd door de evolutie van het kapitalisme intussen achterhaald zou zijn. Deze these, die ook Habermas vanzelfsprekend lijkt te vinden, komt er in het kort op neer dat de welvaartstaat de arbeidersbeweging in het kapitalistische systeem heeft ingelijfd door haar eisen te compenseren met vergoedingen die conform zijn aan dat systeem. Het revolutionaire élan van de arbeiders wordt via maatregelen als loonsverhoging ('koopkracht') en betaalde vakanties afgevoerd naar de kanalen van het private consumptiegedrag zodat het risico op manifeste conflicten voortaan minimaal kan blijven. Honneth vraagt zich af in hoeverre deze these - vanuit een ideologiekritisch standpunt - overeind kan blijven. Wanneer, bijvoorbeeld, werkloze arbeiders hun maandelijkse uitkering de facto aanvaarden, dan volgt daaruit niet dat zij ook in de normatieve zin met deze situatie instemmen.

In deze context brengt Honneth in herinnering dat een kritische theorie in de links-hegeliaanse traditie aan een aantal eisen moet voldoen die met haar praktische ambitie samenhangen. De theorie probeert maatschappelijke wantoestanden recht te trekken door het bewustzijn daarvan in de samenleving aan te scherpen en sociale groeperingen bij te staan in hun strijd tegen verdrukking en uitbuiting. Deze praktische ambitie wordt vertaald in twee methodische vereisten die samen moeten garanderen dat de theorie wel degelijk aansluit bij de maatschappelijke praktijk waarin ze invloed wil hebben.

De eerste vereiste kwam hierboven al ter sprake en heeft betrekking op de principes, normen of idealen die de theorie als een kritische maatstaf hanteert. In haar diagnose van wantoestanden of pathologische evoluties houdt de theorie de maatschiappij een kritische spiegel voor in de vorm van een normatief ideaal voor Marx: de socialistische samenleving - waarop zij als theorie reeds anticipeert. De eerste methodische vereiste luidt nu dat deze kritische norm, dit ideaal, afkomstig moet zijn uit de maatschappelijke praktijk zelf. Het volstaat niet om die norm filosofisch te bedenken - zoals de principes uit Rawls' theorie van rechtvaardigheid. In een materialistisch, ideologiekritisch kader heeft alle gedachtegoed, elke vorm van kennis, elke theorie zijn wortels in een maatschappelijke praktijk waarbij ze aansluit. Terwijl de traditionele theorie haar eigen ontstaansvoorwaarden miskent of negeert, moet een kritische theorie haar eigen maatschappelijke afkomst uitdrukkelijk mee in rekening brengen. En dus moet ze aantonen dat de norm(en) die zij hanteert, verankerd zijn in de praktijk die ze kritisch evalueert.

Om recht te doen aan haar praktische intentie moet de theorie, ten tweede, haar kritisch standpunt verbinden met een 'maatschappelijke drager', dit is een groep van mensen die op zijn minst geneigd zijn om het ideaal waarop de theorie anticipeert, ook effectief in praktijk te brengen. Bij Marx was deze drager vooraf 
bepaald: het proletariaat was voor hem het vanzelfsprekend 'revolutionair subject' dat het ideaal van de socialistische maatschappij uiteindelijk zou realiseren. Toen die verwachtingen uitbleven en de premissen van het wetenschappelijk marxisme onhoudbaar bleken, is de Kritische Theorie voorzichtiger geworden. Ze legt niet meer op voorhand vast wie die rol concreet op zich zal nemen. Maar in een meer formele zin moet ze zich nog steeds met zo'n maatschappelijke drager kunnen verbinden, als waarborg dat haar normatief ideaal wel degelijk ansluit bij een evolutie die in de praktijk reeds gevolgd wordt.

\section{Kritiek van Honneth op Habermas}

De hierboven vermelde methodische vereisten volstaan om Honneths reactie op Habermas te verduidelijken. In Moralbewußtsein und Klassenherrschaft heeft zijn kritiek vooral betrekking op de laatst genoemde kwestie van de maatschappelijke drager. Volgens Habermas' maatschappijdiagnose heeft het klassenconflict intussen plaats gemaakt voor nieuwe vormen van verzet waarbij politieke voortrekkers en intellectuele elites de overdreven bureaucratisering van de welvaartsstaat aanklagen. ${ }^{10}$ Omdat zij met hun discussies en debatcultuur de communicatieve redelijkheid van de leefwereld verdedigen tegen een invasie van de instrumentele rationaliteit, worden zij naar voor geschoven als de maatschappelijke dragers waarbij de kritische theorie van Habermas bij voorkeur aansluit. Honneth vraagt zich af of in de leefwereld misschien nog andere kritische haarden sluimeren waarvan de hegemoniale Öffentlichkeit geen notitie neemt. Daarbij denkt hij aan latente, weinig gearticuleerde vormen van protest die onder de drempel van de beredeneerde argumentatie blijven en bijgevolg niet ter sprake komen in het publieke debat. Honneth vreest dat dergelijke bronnen van verzet systematisch, i.e. methodisch geïgnoreerd worden door een Kritische Theorie die zich exclusief afstemt op het kritisch potentieel van discussies met weloverwogen argumenten.

In een latere publicatie, Die soziale Dynamik der Mißachtung "1 luidt het bezwaar dat Habermas' theorie ook te weinig beantwoordt aan de eerste methodische vereiste inzake de afkomst van de kritische norm. Voor Habermas is deze norm gegeven met het kritisch ideaal van een ongedwongen (herrschaftsfreie) consensus waarop de communicatieve redelijkheid volgens hem in wezen gericht is. Het 'ongedwongen' karakter van deze consensus slaat op de ideale omstandigheden van een discussie tussen gelijken waarin sociale machtsverhoudingen of strategische motieven het moeten afleggen tegen de kracht van het beste argument. Habermas' kritische theorie anticipeert dus op een (utopische) maatschappij waarin deze ideale omstandigheden gerealiseerd zijn. 
Honneth erkent ten overvloede dat Habermas de links-hegeliaanse traditie bevrijd heeft uit het negativisme waarin ze ten tijde van Horkheimer en Adomo verzeild was geraakt. Maar hij wil ook de prijs van deze redding in rekening brengen. Want in een soort 'terugkeer naar Kant' leidt Habermas zijn kritische norm af uit een theoretische analyse van het 'communicatieve handelen' dat hij strikt onderscheidt van het 'doelrationele handelen'. Het principe van de ongedwongen consensus omvat de voorwaarden die in een 'ideale gesprekssituatie' verondersteld zijn om met argumenten tot een redelijke overeenstemming te komen. ${ }^{12}$ In de concrete discussiepraktijk is het ideaal uiteraard nooit helemaal gerealiseerd. Maar volgens Habermas zullen concrete sprekers in hun zoektocht naar consensus toch voortdurend anticiperen op die ideale gesprekssituatie. In déze (semi-transcendentale) zin zou de kritische norm van Habermas reeds werkzaam zijn in concrete discussies en dus ook aansluiten bij de maatschappelijke praktijk. Voor Honneth echter is deze aansluiting te zwak om recht te doen aan de praktische ambitie van de links-hegeliaanse kritiek. Sociale wanverhoudingen die tot uitbuiting, verdrukking of vernedering leiden zo luidt zijn argument - worden in de praktijk helemaal niet ervaren als een inbreuk op de talige principes die Habermas tot kritische norm verheft. Wel wekken ze bij de slachtoffers een morele verontwaardiging die volgens Honneth heel wat interessanter is voor de verklaring van maatschappelijke (r)evoluties dan de principes van Habermas. Honneth besluit dan ook dat Habermas' kritische theorie te weinig in de realiteit verankerd is en nood heeft aan een sociaalpsychologische basis die haar aansluiting bij de praktijk versterkt. In het nawoord van zijn meest bekende werk, Kampf um Anerkennung ${ }^{13}$ heeft hij naar eigen zeggen deze basis willen leveren.

\section{'Erkenning': kritisch principe of ideologie ?}

In Kampf um Anerkennung begrijpt Honneth de emancipatorische verworvenheden van de modeme maatschappij als het resultaat van een langdurige strijd om erkenning waarin mensen opkwamen voor de bescherming van hun lichamelijke integriteit, de erkenning van hun rechten en de waardering van hun bijdrage aan de samenleving. Deze drie vormen van erkenning - die Honneth afkort als 'zorg', 'respect' en 'waardering' - hebben na allerlei conflicten waarin ze op tal van manieren en door steeds meer mensen werden opgeëist, een algemene geldingskracht verkregen die vandaag in diverse maatschappelijke instituties belichaamd wordt. Voor Honneth geven ze alle drie samen de kritische drempel aan van de erkenning die mensen van elkaar en van de samenleving mogen verwachten, en die ze ook nodig hebben om zich als mens te kunnen ontplooien. In de negatieve zin zou dit betekenen dat niet-erkenning op één van deze vlakken volstaat om de sociale, intersubjectieve basis van de persoonlijke 
identiteit te ondermijnen.

Omdat ze de voorwaarden omvatten van een ongeschonden identiteit, hanteert Honneth deze drie vormen van erkenning, als kritische principes die in de maatschappelijke praktijk verbonden zijn met de sfeer van het recht, de arbeid en het private leven. Op grond van deze principes - welke inhoudelijk rijker zijn dan het formele criterium van Habermas - kan de Kritische Theorie zich aansluiten bij diverse sociale bewegingen die, bijvoorbeeld, reageren tegen de genitale verminking van vrouwen in naam van traditie of religie (erkenning van lichamelijke integriteit) of die ijveren voor migrantenstemrecht (erkenning van rechten). Maar ook de neoliberale deregulering van de arbeidsmarkt kan in het licht van Honneths criteria veroordeeld worden, omdat ze de 'waardering' in het gedrang brengt die mensen nodig hebben om hun specifieke bekwaamheden en prestaties te kunnen beschouwen als een betekenisvolle bijdrage aan de samenleving waarin hun leven zich afspeelt.

Honneth heeft de sociaal-psychologische basis en de methodische opbouw van zijn theorie in talrijke publicaties uitgewerkt. Hij heeft ze ook verdedigd tegen het verwijt dat het modieuze discours over erkenning en identiteit de aandacht afleidt van het onrecht dat nog steeds met de economische herverdeling samenhangt. ${ }^{14}$ Maar belangrijker in dit verband is de verdachtmaking dat publieke vormen van erkenning op zich reeds ideologisch zijn omdat ze mensen conformeren aan de gevestigde orde. Erkenning zou dan als zodanig bewerkstelligen dat mensen zich vrijwillig voegen naar de orde waarin ze erkend worden. In dit licht zou zelfs een ideologiekritische theorie die rond het concept van erkenning is opgebouwd, meteen al zelf ten prooi vallen aan de ideologische verblinding waartegen ze zich wil wapenen.

In Anerkennung als Ideologie ${ }^{15}$ beaamt Honneth dat publieke praktijken van erkenning en bevestiging voor Althusser het standaardmechanisme vormen waarmee elke ideologie opereert. $\mathrm{Ze}$ bevorderen de 'subjectiverende onderwerping' waarmee Althusser de vorming van het subject en diens identiteit verklaart. Het subject wordt gevormd in de onderwerping aan een systeem van regels en praktijken waaraan het tegelijk zijn sociale identiteit ontleent. De identiteit is aldus het resultaat van een conditioneringsproces waarbij subjecten door allerlei vormen van publieke bekrachtiging precies dat zelfbeeld en die gedragingen gaan ontwikkelen die nodig zijn om de gevestigde orde in stand te houden.

Edoch, omdat Althusser de betekenisinhoud van de notie 'erkenning' van meet af aan gelijkschakelt met 'conditionering', 'conformering' blijft er geen ruimte meer over voor de positieve, emanciperende inhouden die Honneth aan die notie wil toekennen.

Honneths reactie op Althusser is dus gelijkaardig aan Habermas' kritiek op de veel te eenzijdige invulling die Horkheimer en Adorno aan het concept 
'rationaliteit' hadden gegeven. Wanneer de rationaliteit als zodanig gelijkgeschakeld wordt met controle en beheersing, dan is er geen 'buiten' meer van waaruit de desastreuze evoluties die ze aanklagen op rationele gronden bekritiseerd kunnen worden. In dezelfde zin is Althussers invulling van de notie 'erkenning' dermate eenzijdig dat ze geen plaats meer laat voor vormen van erkenning die mensen nodig hebben om zich te kunnen weren tegen de conformerende, 'ideologische' praktijken die Althusser aanklaagt. Vanuit een ideologiekritisch standpunt zijn die praktijken ideologisch omdat ze deze weerbaarheid ondergraven en de autonomie in de kiem smoren die de Kritische Theorie nu net wil bevorderen. Kortom, terwijl 'erkenning' voor Althusser alleen een strategie is om mensen te onderwerpen aan de gevestigde orde, omvat diezelfde notie bij Honneth de drie vormen die hij tezamen als kritische norm hanteert om de gevestigde orde in vraag te kunnen stellen.

Maar hoe kunnen de conformerende, ideologische vormen van erkenning waarop Althusser wijst, in de praktijk onderscheiden worden van de emanciperende vormen die Honneth daartegenover stelt?

Honneth merkt op dat het ideologische gehalte van publieke discours en praktijken van erkenning meestal retrospectief wordt vastgesteld. De trouw van de slaaf aan zijn meester of de onbezoldigde, belangeloze inzet van vrouwen zijn voor de hand liggende voorbeelden van kwaliteiten die ooit een grote publieke waardering genoten en waaraan menige slaaf of vrouw haar fierheid ontleende. Pas achteraf, na de emancipatiestrijd die deze praktijken veroordeelde en omverwierp, wordt ook het ideologisch gehalte ervan onderkend. En wel op basis van de nieuwe normatieve criteria die dankzij de emancipatiestrijd afgedwongen werden, en die in de huidige, westerse samenleving ook een institutionele geldingskracht verwierven. Daarom is het voor ons nagenoeg vanzelfsprekend geworden dat mensen gelijkelijk respect verdienen en gelijke rechten genieten, ongeacht hun huidskleur of geslacht. Praktijken en discours die daar flagrant tegenin gaan noemen we vandaag dan ook regelrecht 'racistisch' of 'discriminerend', en niet 'ideologisch'. 'Ideologisch' kunnen ze maar zijn, wanneer ze een hele samenleving blind maken voor de wantoestanden die ze - achteraf bezien - in stand hielden. Die verblinding toont zich in het vanzelfsprekende karakter waarmee praktijken als slavernij of de onthouding van rechten aan vrouwen te hunner tijd algemeen aanvaard en gelegitimeerd werden.

Als echter het ideologisch gehalte van een publiek discours pas achteraf vast te stellen is, dan wordt de bovenstaande vraag des te prangerder: hoe kunnen we conformerende vormen van erkenning in de huidige samenleving onderscheiden van emanciperende? De zin en de bestaansreden van een ideologiekritische theorie zou immers vervallen wanneer ze - zoals de uil van Minerva - alleen 
maar achteraf haar voorwerp vindt.

Honneth stelt drie voorwaarden op waaraan publieke vormen van erkenning vandaag moeten voldoen om effectief de ideologische impact te kunnen hebben die een Kritische Theorie moet opsporen. Discours die willen aanzetten tot racisme, discriminatie of homohaat kunnen niet langer fungeren als een ideologie, voor zover ze geen positief zelfbeeld induceren dat mensen vrijwillig op zich zouden nemen om hun sociale positie te verbeteren of simpelweg 'erbij te horen'. In de context van onze huidige, normatieve 'vanzelfsprekendheden' tasten dergelijke discours veeleer het zelfbeeld aan en worden ze in het algemeen spontaan ervaren als een vorm van uitsluiting of vernedering. Ideologieën waarvan de werkzaamheid op sociale erkenning berust, moeten dus in eerste instantie bijdragen tot een betere integratie van diegenen aan wie ze appelleren, en dat is enkel mogelijk door een positief zelfbeeld aan te reiken.

Om dit effect te bereiken dienen ideologieën, ten tweede, een discours te hanteren dat realistisch en geloofwaardig is. Het ideologische discours moet daarom gebruik maken van het gangbare vocabularium waarin eigentijdse waarden en overtuigingen tot uiting komen. Omdat 'zelfstandigheid', 'autonomie' en 'originaliteit' in de huidige westerse maatschappij als centrale waarden gekoesterd worden, zal een conformerend, normaliserend discours doorgaans ervaren worden als een inperking van de eigen mogelijkheden en een aantasting van het zelfbeeld dat door deze waarden ondersteund wordt. Zelfs al wordt het normaliserende discours in de literaturur nog steeds aangehaald als het prototype van de ideologie, toch heeft zo'n discours in de praktijk van vandaag geen ideologische impact meer.

Dit brengt ons tenslotte bij de derde voorwaarde waaraan een discours van erkenning moet voldoen om als ideologie te kunnen fungeren: het moet appelleren aan een vernieuwende waarde die een bijzondere sociale distinctie toelaat ten aanzien van de gevestigde patronen.

Een publiek discours dat aan de drie voorgaande voorwaarden beantwoordt, kan via de bekrachtiging van een positief zelfbeeld de bereidheid wekken om zich uit vrije wil te conformeren aan de vereisten van het systeem, de eigen autonomie aan de kant te laten en zich te onderwerpen aan de gevestigde machtsverhoudingen. In de kritische zin van het woord zou een dergelijk discours dan kunnen doorgaan voor een 'ideologie van erkenning'.

Om het resultaat van zijn analyse te illustreren vindt Honneth onder de veelheid van vernieuwende waarderingsdiscours die zich vandaag in onze cultuur profileren, een bijzondere kandidaat die voor de bovenstaande omschrijving in aanmerking kan komen. Het richt zich tot de werknemers van de laatkapitalistische landen en appelleert aan hun 'managementkwaliteiten', al blijft het wel onduidelijk in hoeverre zij die bezitten. Loontrekkers (maar ook studenten) ${ }^{16}$ 
worden beschouwd en aangesproken als 'ondernemers' die van de werkgever (of educatieve instelling) de verantwoordelijkheid krijgen om zelf hun carrière uit te stippelen en hun taken af te stemmen op de andere 'projecten' die zij in hun 'levensplan' hebben voorzien. In dit management-discours wordt voortdurend de indruk gewekt dat de bevordering van kwaliteiten als ondernemingschap, flexibiliteit, verantwoordelijkheid en creativiteit aan de kant van de werknemer bijdragen tot de autonome organisatie van het eigen leven en de ontplooiing van de eigen persoonlijkheid. Daarbij is het opvallend dat al deze kwaliteiten bekwaamheden veronderstellen die ooit uitsluitend voor de 'klassieke' ondernemer - de werkgever, de kapitalist - gereserveerd waren. Maar nu worden diezelfde vermogens dus ook toegeschreven aan werknemers en studenten, met een gunstige beïnvloeding van hun zelfbeeld tot gevolg.

Dat de publieke appreciatie van bovenstaande managerskwaliteiten voldoet aan de conceptuele voorwaarden van een ideologisch discours, behoeft verder geen betoog. Wel is het nog onduidelijk waarom dat discours ook effectief ideologisch zou zijn. Want waarom zouden we er niet met enige welwillendheid van uitgaan dat het waarderingsaanbod werkelijk de autonomie en de persoonlijke ontplooiing van werknemers bevordert? Nog niet zo lang geleden werd het vermogen om met een politieke stem invloed uit te oefenen op het publieke beleid, eveneens alleen maar toegeschreven aan een beperkte, ondermemende klasse. Het discours dat dit vermogen naderhand ook aan arbeiders en vrouwen toekende, voldeed wellicht ook aan de voorwaarden voor een ideologisch discours. Maar toch zouden we dat - achteraf - niet als zodanig karakteriseren.

Bovenop de drie conceptuele voorwasden moet er dus nog een vierde, materiële component bijkomen die de reële geloofwaardigheid van het managementdiscours in rekening brengt. Die reële geloofwaardigheid slaat dit keer niet op de overtuigingskracht waarmee dat discours aan de doelgroep appelleert, maar op de materiële voorwaarden die nodig zijn om de aangereikte erkenning ook effectief te realiseren. Deze vierde, doorslaggevende vereiste kan gemakkelijk verduidelijkt worden aan de hand van het bovenstaande voorbeeld: de erkenning van een stemrecht. Om het niveau van het louter symbolische te overstijgen moeten heel wat praktische consequenties en maatregelen volgen die in de praktijk garanderen dat dit stemrecht daadwerkelijk kan uitgeoefend worden.

Op grond van dit laatste criterium lijkt het discours dat de ondernemerskwaliteiten van werknemers in de verf zet, inderdaad ideologisch te zijn. Want de flexibiliteit die werknemers vrijwillig aan de dag (moeten) leggen, en de verantwoordelijkheden die ze - althans op het eerste gezicht - graag op zich willen nemen, spelen vooral in het voordeel van een neoliberaal, dynamisch kapitalisme dat de winst voor de belegger laat prevaleren op de belangen van 
werknemers en precies daardoor een deregulering van de arbeid in de hand werkt. De institutionele voorwaarden die zouden moeten garanderen dat werknemers de gewaardeerde competenties daadwerkelijk kunnen uitoefenen, zijn volgens Honneth niet gegeven of slechts zeer oppervlakkig uitgebouwd. Maar onder druk van de steeds dreigende werkloosheid, voelen heel wat werknemers zich opgeroepen om de gewenste motivering, het aanpassingsvermogen en alle gewaardeerde competenties van het ondernemerschap te simuleren en zich te gedragen alsof ze in hun arbeidstaak de zin van hun leven vervullen.

\section{Besluit: een richtlijn voor het onderzoek van hedendaagse ideologieën}

De vraag of een bepaald discours al dan niet ideologisch is wordt niet langer beslecht op grond van een bijzonder weten omtrent de ware werkelijkheid, dat de Kritische Theorie voor zichzelf zou kunnen opeisen. In Anerkennung als Ideologie geeft Honneth aan hoe hij met een Kritische Theorie die op diverse vormen van erkenning berust, een ideologisch discours vandaag zou identificeren. Kernachtig samengevat luidt de conclusie dat zo'n discours de erkenning die ze belooft in (de) werkelijkheid niet kan waar maken.

In het onderzoeksprogramma dat Honneth met Martin Hartmann uitwerkte - Paradoxien des Kapitalismus. Ein Forschungsprogramm - geeft hij nog een bijkomende aanwijzing waarmee een ideologiekritische benadering van het huidige kapitalisme rekening moet houden. ${ }^{17}$ Het kapitalistisch systeem maakt vandaag een aantal transformaties door die Honneth onder de noemer van de 'neoliberale kentering' samenvat. Daartoe behoren onder meer de toenemende macht van transnationale ondernemingen, de globalisering van financiële stromen en niet in het minst de gestage afbrokkeling van de grenzen waarmee de welvaartstaat de ergste uitwassen van de kapitalistische winstcreatie tot voor kort wist in te dijken.

In deze context vereist de ideologiekritiek een andere aanpak dan in de Frankfurter Schule in de afgelopen vijftig jaar gebruikelijk was. Tot dusver werd de ontwikkeling van de kapitalistische maatschappij geanalyseerd met behulp van een welbepaald schema dat op de diagnose van contradicties was afgestemd. Volgens dit schema genereert de harde economische rationaliteit van het kapitalistisch systeem structurele machtsverhoudingen die na verloop van tijd in tegenstelling komen te staan met de redelijke verworvenheden die het emancipatorisch project van de moderniteit eveneens voortbracht. Ook Habermas maakt gebruik van dat contradictieschema wanneer hij vaststelt dat de legitimerende basis waarop het burgerlijke kapitalisme nog kon terugvallen, uiteindelijk door de kapitalistische logica zélf ondergraven wordt. Het kapitalisme omvat een zelfdestructief moment omdat het vanuit zichzelf niet bij 
machte is om nieuwe legitimerende schema's te leveren voor de ongelijkheden die het zelf genereert. Daarom zal de kapitalistische logica onvermijdelijk opbotsen tegen de eisen van een universalistische moraal, die mettertijd terrein wint en deze ongelijkheden aanklaagt. ${ }^{18}$

Met de notie van 'paradoxale contradicties' wil Honneth het bovenstaande contradictieschema bijstellen. Paradoxale contradicties treden op wanneer de inspanning om bepaalde doelen te bereiken - zoals het bevorderen van autonomie of gelijke kansen voor allen - in de praktijk effecten oproept die de realisering van die doelen tegenwerken. Volgens Honneth brengt de neo-liberale kentering heel wat paradoxale effecten teweeg die het klassieke schema doorbreken. In de diagnose van Habermas werkt dat schema met de tegenstelling tussen diverse domeinen die - in (de) theorie - duidelijk af te bakenen zijn: de kapitalistische logica versus de emancipatiestrijd, de instrumentele of strategische rationaliteit versus de communicatieve redelijkheid, het systeem versus de leefwereld.

Wat het huidige kapitalisme echter typeert, is nu net het vervagen van de grenzen tussen deze domeinen. Vandaag is het hoogst onduidelijk geworden welke praktijken emanciperen dan wel (onderwerpend) conformeren. Waarderingspatronen die op het eerste gezicht de communicatieve redelijkheid dienen, zullen bij nader toezien vooral de strategische rationaliteit bevorderen. De theoretische grenstrekking tussen leefwereld en systeem gaat voorbij aan de actuele verstrengeling van beide domeinen. Hierdoor kan de kapitalistische logica beter dan ooit inspelen op de verworvenheden van de emancipatiestrijd en wordt het ook mogelijk dat de idealen die deze strijd aanvankelijk inspireerden, ideologisch ten dienste komen te staan van de kapitalistische winstcreatie. Het ideologisch discours waarin werknemers gestimuleerd worden om zich als ondernemers te gedragen kan hiervan een voorbeeld zijn. De politieke en ethische idealen van autonomie en zelfrealisatie die ooit een emanciperende werking hadden, worden aangesproken en ingeroepen om mensen te conformeren aan de kwalificaties (flexibiliteit, creativiteit) waaraan het neoliberale kapitalisme vandaag behoefte heeft.

Dit voorbeeld is treffend om de paradoxen van het kapitalisme te evoceren die Honneth en Hartmann met hun onderzoeksprogramma op het spoor willen komen en waarvoor de notie van de 'paradoxale contradicties' een beter instrument lijkt dan het klassieke contradictieschema. De werkhypothese voor dat onderzoek luidt in het kort dat de kapitalistische economie alle segmenten van het maatschappelijke leven onder druk zet om zich aan te passen aan de neoliberale kentering die zich vandaag voltrekt. Voor de traditie van de Frankfurter Schule is deze situatie nieuw omdat de aanpassingen waartoe het kapitalisme druk uitoefent, niet langer ingaan tegen de moderne idealen die de 
kritische theorie wil beschermen en bevorderen. Wel wordt de betekenis van die idealen zodanig gemodificeerd dat hun emancipatorische inhoud op zijn minst gezegd ambigu wordt.

Voor de Kritische Theorie omvatten deze idealen nog steeds een potentieel. Maar in de praktijk van vandaag kunnen diezelfde idealen evengoed ten dienste van de kapitalistische logica fungeren. De bevordering van die idealen leidt dus niet eenduidig tot een grotere .weerbaarheid tegen de druk van het systeem. Paradoxaal genoeg kan ze die weerbaarheid ook ondermijnen en zo het tegengestelde effect bewerken van wat ze beoogt: in plaats van weerstand te bieden gaan mensen zich vrijwillig aanpassen aan de imperatieven die de neoliberale kentering vandaag aan hen oplegt.

In de termen van Habermas vat Honneth deze mogelijkheid samen in de sloganeske bewering dat het systeem zich vandaag maar al te graag laat koloniseren door de leefwereld. In de termen van Marx laat deze slogan zich als volgt vertalen: van de idealen die de ideologiekritiek tot dusver inriep om een samenleving uit haar ideologische verblinding te bevrijden, gaat intussen ook een verblindende straling uit.

\section{Noten}

1 Voor een heldere bespreking van deze kritiek, zie Wellmer A., 'Natuurrecht und praktische Vernunft. Zur aporetische Entfaltung eines Problems bei Kant, Hegel und Marx', in:, Endspiele: Die Unversöhnliche Moderne, Essays und Vorträge, Wellmer A. (red.), Suhrkamp, Frankfurt a.M., 1993, pp. 94-154.

2 Honneth A., 'Pathologien des Sozialen. Tradition und Aktualität der Sozialphilosophie.', in: Das Andere der Gerechtigkeit, Aufsätze zur praktischen Philosophie, Honneth A. (red.),Suhrkamp, Frankfurt a.M., 2000, pp. 11-70.

3 Over het hegeliaanse gehalte van Marx' visie op de ideologie, zie ook: Márkus G., 'Die Welt menschlicher Objekte. Zum Problem der Konstitution im Marxismus', in: Arbeit, Handlung, Normativität. Theorien des Historischen Materialismus 2, Honneth A. \& Urs J.(red), Suhrkamp, Frankfurt a.M., 1980, pp. 12-136.

4 Honneth A., 'Eine soziale Pathologie der Vernunft. Zur intellektuellen Erbschaft der Kritischen Theorie', vert. đ. Voirol O. en opgenomen in: La société du mépris. Vers une nouvelle Théorie critique, Honneth A. (red.), La Découverte, Paris, 2006, pp. 101-131.

5 Honneth A. \& Voirol O., 'La Théorie critique de l' École de Francfort et la théorie de la reconnaissance. Entretien conduit les 5 et 8 octobre 2001 à Francfort', vert. d. Voirol O, in:, La société du mépris, Honneth A., 2006, pp. 151-181.

6 Een meer uitvoerige historiek van de ontwikkelingen die zich binnen de Frankfurter Schule hebben afgespeeld, is te vinden in: Honneth A, 'Über die Möglichkeiten einer erschließenden Kritik. Die "Dialektik der Aufklärungu im Horizont gegenwärtiger Debatte über Sozialkritik, in: Das Andere der Gerechtigkeit, Honneth A. (red.), 2000, pp. 70-88, en Honneth A., 'Kritische Theorie. Vom Zentrum zur Peripherie einer Denktradition', in: Die Zerissene Welt des Sozialen, Honneth A. (red.), Suhrkamp, Frankfurt a.M., 1999, pp. 25-73. 
7 Honneth A., 2000, p. 49.

8 Habermas, J., Technik und Wissenschaft als >Ideologie<, Suhrkamp, Frankfurt a.M., 1970.

György Márkus merkt op dat Habermas hiermee een nieuwe interpretatie geeft van een dichotomie die ook reeds in het 'productieparadigma' van Marx besloten lag. Door zijn kritische theorie in contrast met Marx te typeren, legt Habermas dus een overdreven klemtoon op het 'nieuwe karakter' ervan. In: Márkus G., 1980, p. 17.

9 Honneth A., 'Moralbewußtsein und Klassenherrschaft', in: Das Andere der Gerechtigkeit, Honneth A. (red.), 2000, pp. 110-133.

10 Habermas J., Legitimationsprobleme im Spätkapitalismus, Suhrkamp, Frankfurt a.M., 1973.

11 Honneth A., 'Die soziale Dynamik von Mißachtung. Zur Ortsbestimmung einer kritischen Gesellschaftstheorie', in: Das Andere der Gerechtigkeit, Honneth A. (red.), 2000, pp. 88-110.

12 Namelijk inclusiviteit (niemand wordt uitgesloten uit het gesprek), gelijkheid tussen de deelnemers en vrijheid van macht of dwang. Habermas J., Theorie des kommunikativen Handelens, Suhrkamp, Frankurt a.M., 1981.

13 Honneth A., Kampf um Anerkennung. Zur moralischen Grammatik sozialer Konflikte, Suhrkamp, Frankfurt a.M., 1994.

14 In Umverteilung oder Anerkennung? dat de discussie met Fraser weergeef, pareert Honneth dit verwijt met de bemerking dat de principes van respect en waardering de (her)verdelende rechtvaardigheid omvatten .Uit de dialoog tussen beide auteurs kan blijken dat Frasers terechte kritiek op de eenzijdigheden van een al te dominant discours waarin 'erkenning' centraal staat, aan het adres van Honneth enigszins misplaatst is. Honneth A. \& Fraser N., Umverteilung oder Anerkennung? Eine politisch-philosophische Kontroverse, Suhrkamp, Frankfurt a.M., 2003.

15 Honneth A., 'Anerkennung als Ideologie', in: West-End. Neue Zeitschrift für Sozialforschung, 2004, pp. 51-70.

16 Honneth heeft het enkel over loontrekkers. Dat de teneur van zijn kritiek ook opgaat voor studenten heb ik er zelf aan toegevoegd, zie: Haverhals B., 'The normative foundations of research-based education: Philosophical notes on the transformation of the modern university idea', in: Studies in Philosophy and Education, 26 (5), 2007, pp. 419 432.

17 Honneth A., in: Berliner Debatte Initial, 2004, pp. 4-17.

18 Zie hiervoor: Habermas, J., Legitimationsprobleme im Spätkapitalismus, Suhrkamp, Frankfurt a.M., 1973. 